\title{
IGNITABILITY SMALL ATTACK FLAME FIRE TEST OF GYPSUM COMPOSITE REINFORCED WITH NATURAL FIBRES
}

\author{
JIŘÍ TESLÍK*, MARKÉTA HOŠŤÁLKOVÁ, NIKOLA VAV̌̌ÍNOVÁ \\ Faculty of Civil Engineering, VŠB TUO, Ludvíka Podéště 1875/17, 708 33, Ostrava-Poruba, Czech Republic \\ *E-mail: jiri.teslik@vsb.cz
}

\begin{abstract}
Ignitability is one of the parameters that characterize the behaviour of building materials on flame action. The Ignitability Small Attack Flame fire test is used for the classification of building products by their reaction to fire. On the basis of the Ignitability fire test it can be determined that the tested material will be classified into the class E by reaction to fire. The Ignitability Small Attack Flame fire test precede the Single Burning Item fire test, that is used for classification of building products to class $D$, $C$, $B, A 2$. The results of the Ignitability fire test were carried out as part of the research on the properties of gypsum composite with natural fiber reinforcement. As part of the research series of ignitability tests on two types of gypsum composite were carried out. The first type was a gypsum composite reinforced with straw fibres. The second type was composite reinforced with wooden fibres. Developed composite materials could be used in the future as board materials and therefore the determination of their fire parameters is a very important part of research. The results of the fire tests have shown that the developed material has a very good flame resistance.
\end{abstract}

Keywords: reaction to fire, crushed straw, wooden fibre, ignitability, fire resistance, gypsum composite, natural fibres

\section{Introduction}

The gypsum or plaster is one of the most often used materials in the civil engineering. Usually it is applied in the form of plasterboards without any reinforcement, for example, cladding boards is unusable as supporting construction. To improve the mechanical properties of plasterboards, fibrous materials such as cellulose or glass fibre are added. The main purpose of the research is to clarify whether natural hemp fibres or straw could be used as the reinforced materials. The second purpose is to verify the use of non-standard types of natural materials such as starch. The research explores the impact of the natural fibre on mechanical properties of the plasterboards (compressive strength, tensile strength, flexural strength). Also, the most suitable type of binders in production technologies of reinforced composite materials and its mechanical properties is determined, for example, shape, length and amount of fibres, are tested. Finally, the research deals with the mechanical, fire, acoustic and thermal properties of the examined materials.

Buildings whose structures contain natural (organic) building materials tend to have lower fire resistance than buildings constructed of synthetic materials. The fire characteristics of natural (organic) materials are assessed by low degrees of fire resistance. In buildings where flammable natural materials are used, fire resistance can be increased by protecting flammable materials by covering with non-combustible materials. Usually gypsum boards are used to protect flammable materials. The fire resistance of building structures (walls, ceilings, roofs) is mainly influenced by the reaction to fire class of single-use materials. According to the Czech legislation, the fire resistance of building structures or constructions is characterized by the minimum fire resistance time - REI [1]. Fire characteristics of single building materials are characterized by their reaction to fire. Reaction to fire shows how this material contributes to fire, smoke and burning droplets. According to the European Union legislation and according to the standard ČSN EN 13501-1 [2] building materials are classified into seven classes. The determination of the reaction-to-fire class of building materials and the determination of the fire resistance of building structures shall be carried out on the basis of fire tests.

This is an open-access article distributed under the terms of the Creative Commons Attribution-NonCommercial 4.0 International License (https://creativecommons.org/licenses/by-nc/4.0/), which permits unrestricted use, distribution, and reproduction in any medium for non-commercial purposes, provided the original author and source are credited, a link to the CC License is provided, and changes - if any - are indicated. 


\section{Classification system of building products and materials by their reaction to fire}

Within the scope of unification, it is necessary to specify requirements for the classification of building materials for products so as to comply with the fire safety according to ČSN EN 13501-1 Fire classification of construction products and building elements - Part 1: Classification using test data from reaction to fire tests [2] Table 1 [5].

We classify the products into seven classes of reaction to fire marked $A 1, A 2, B, C, D, E, F$. Class $A 1$ and $A 2$ contain non-flammable products, class $B$ to $F$, products with increasing flammability. Classification can be determined by application tests or procedures required for this selected product.

Reaction to fire means the reaction of a product under specified conditions by the contribution of its own decomposition to the development of the fire to which it is subjected. For the classification of the reaction-to-fire class, the product is subjected to appropriate test methods - a fire test (for classification in classes $A 1, A 2$ ), calorific value (for classification in classes $\mathrm{A} 1, A 2$ ), single burning test (for classification in classes $A 2, B, C, D$ ), flammability test (for class $B, C, D, E$ ). The reaction-to-fire classification of the product under consideration is determined by comparing the test results with the classification parameters in EN 13501-1 [2]. When the product does not meet class $E$ requirements, then it is classified in class $F$.

In the case of products classified $A 2, B, C$ and $\mathrm{D}$, according to ČSN EN 13501-1 [2], the supplementary classification $s 1, s 2, s 3$ according to smoke evolution and $d 0, d 1, d 2$ are determined according to the flame of the flaming droplets. The value of the digit for the supplementary classification $s, d$ indicates the rate of smoke and droplet formation. When the value of products is higher, the smoke and the drops is higher too.
Each material describes a classification report that provides a unification way of classifying.

\section{The ignitability fire test by a small-time attack flame of crushed straw}

An ignitability fire test was also part of the research on the properties of straw-based fiber materials. The ignitability fire test on a crushed straw was carried out in the first phase of research on composite materials based on straw and plaster in 2016. The ignitability fire test by a small-time attack flame could be used for classification in to the class $E$ by reaction to fire of tested materials (Table 1). If the material during fire test meets the requirements it could be classified into classes $D$ to $A 1$. The ignitability fire test of blown (cellulose, straw) building material is carried out in the special furnace. The test container filled by the tested material is placed in this furnace. The test container is in the furnace situated in vertical position. The test container for blown materials is made of wire mesh. Dimensions of the container sample are $230 \mathrm{~mm}$ (high) $\times 90 \mathrm{~mm}$ (width) $\times 40 \mathrm{~mm}$ (thickness). The test container dimensions and material specification are shown and described in the standard [4] supplement $C$. Tested materials into tested container were filled by hand. If the tested container is filled by the tested material, the container is placed into the furnace (Fig. 1). On the exposed surface of the test container two horizontal axes are marked. First is $40 \mathrm{~mm}$ above the bottom edge of the testing container. Second is $150 \mathrm{~mm}$ above the first axis. First axis shows the touchpoint where the gas burner with a small normative flame touches the tested material surface. Angle of burner is $45^{\circ}$ and length of flame must be measured by special meter. Length of the flame could be set up by the regulation of gas supply. At this point, the time at which the flame is

Table 1. Classification using test data from reaction to fire tests [5]

\begin{tabular}{ll}
\hline Class & Characteristic \\
\hline$A 1$ & $\begin{array}{l}\text { Class A1 products will not contribute in any stage of the fire including the fully developed fire. For that reason they } \\
\text { are assumed to be capable of satisfying automatically all requirements of all lower classes. }\end{array}$ \\
\hline$A 2$ & $\begin{array}{l}\text { Satisfying the same criteria as class B for the SBI-test according to EN 13823. In addition, under conditions of a fully } \\
\text { developed fire these products will not significantly contribute to the fire load and fire growth. }\end{array}$ \\
\hline$B$ & As class C but satisfying more stringent requirements. \\
\hline$C$ & $\begin{array}{l}\text { As class D but satisfying more stringent requirements. Additionally under the thermal attack by a single burning item } \\
\text { they have limited lateral spread of flame. }\end{array}$ \\
\hline$D$ & $\begin{array}{l}\text { Products satisfying criteria for class E and capable of resisting, for a longer period, a small flame attack without } \\
\text { substantial flame spread. In addition, they are also capable of undergoing thermal attack by a single burning item with } \\
\text { sufficiently delayed and limited heat release. }\end{array}$ \\
\hline$E$ & Products capable of resisting, for a short period, a small flame attack without substantial flame spread. \\
\hline$F$ & $\begin{array}{l}\text { Products for which no reaction to fire performances are determined or which cannot be classified in one of the classes } \\
A 1, A 2, B, C, D, E .\end{array}$ \\
\hline
\end{tabular}




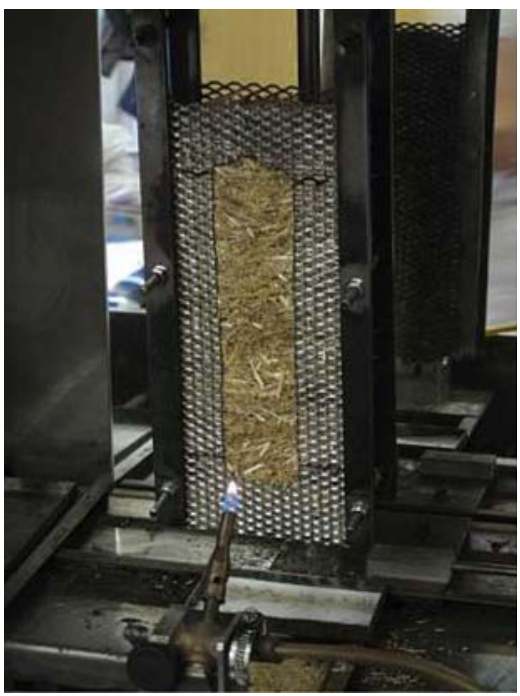

Fig. 1. Test container with crushed straw

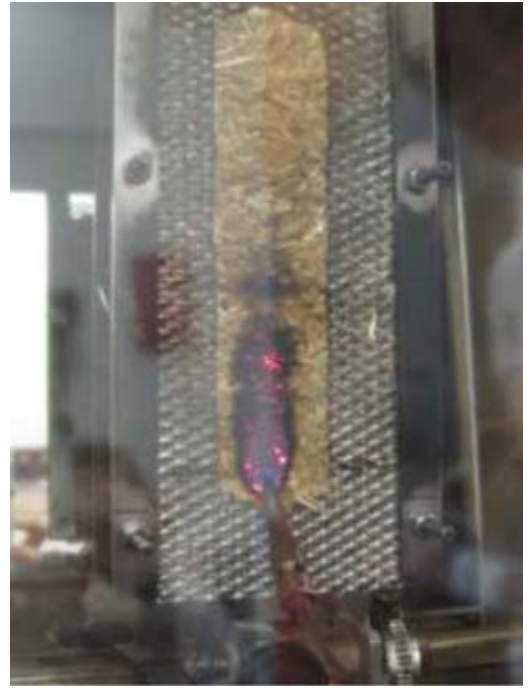

Fig. 2. Crushed straw in the direct exposure to flame

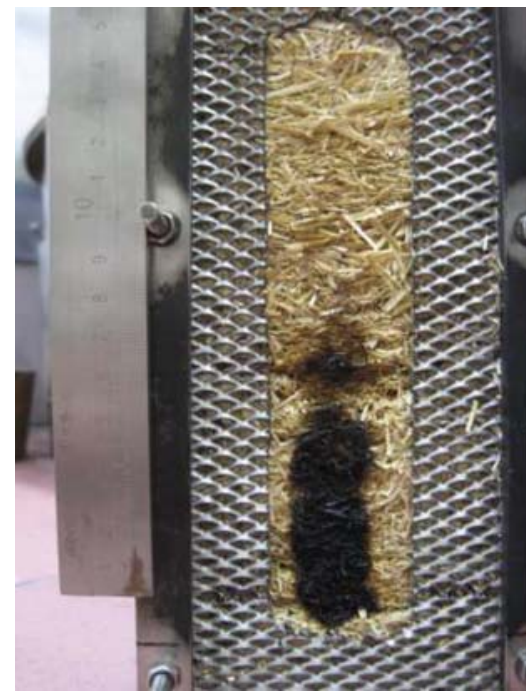

Fig. 3. Crushed straw after fire test

Table 2. Results of the ignitability fire test by a small-time attack flame of crushed straw

\begin{tabular}{lccccccc}
\hline & \multirow{2}{*}{ Units } & \multicolumn{5}{c}{ The measurement results of the test specimen No. } \\
\cline { 3 - 7 } & & 1 & 2 & 3 & 4 & 5 \\
\hline Ignitability Yes/No & - & Yes & Yes & Yes & Yes & Yes \\
Achieving the flame to the mark $150 \mathrm{~mm}$ Yes/No & - & No & No & No & No & No & - \\
Burning time track $150 \mathrm{~mm}$ & s & - & - & - & - & - \\
\hline
\end{tabular}

allowed to act on the test material begins to be measured. Time of the fire test (flame effect) could be 15 seconds or 30 seconds. If the material could be classified in the class $D$ by their reaction to fire, the test duration is 30 seconds. The time duration of crushed straw fire test was 15 seconds. During the fire test two criteria are checked. If the flame ignites the surface of the sample and if the flame spreads from the first horizontal axe (touchdown point) to second horizontal axe $150 \mathrm{~mm}$ above the touchdown point. If the flame spreads to the second horizontal axe the tested material does not meet the requirements of the fire test. Next time before the flame touches the second horizontal axe is measured. - Burning time track $150 \mathrm{~mm}$ criteria. The ignitability fire test is carried out on five test specimens. Crushed straw, used in this test is natural without any chemical additives.
Bulk density of crushed straw filled into tested container was $90 \mathrm{~kg} \cdot \mathrm{m}^{-3}$. During test all five test samples met the test requirements. When the flame touched the crushed straw its surface ignited of orange flame. After 15 seconds the torch has been delayed from the touchdown point and the flame spread stopped $6.5 \mathrm{~cm}$ from the first horizontal axe. The test container and progress of fire test ignitability are shown in Figs 1, 3,4 . The results of the ignitability fire tests of crushed straw are shown in Table 2.

\section{The ignitability fire test by a small-time attack flame of gypsum composite}

The test of flammability of the gypsum composite was performed on eight test specimens. Four test specimens were made with straw and four with wooden fiber con-

Table 3. Percentage and weight proportions of tested series

\begin{tabular}{cccccc}
\hline \multirow{2}{*}{ Series } & \multicolumn{2}{c}{ Gypsum } & & \multicolumn{2}{c}{ Reinforcing straw/wooden fibres } \\
\cline { 2 - 3 } \cline { 5 - 6 } & $\begin{array}{c}\text { Percentage } \\
\text { proportions [\%] }\end{array}$ & $\begin{array}{c}\text { Weight } \\
{[\mathrm{kg}]}\end{array}$ & & $\begin{array}{c}\text { Percentage } \\
\text { proportions [\%] }\end{array}$ & $\begin{array}{c}\text { Weight } \\
{[\mathrm{kg}]}\end{array}$ \\
\hline 1 & 97.5 & 1.17 & & 2.5 & 0.03 \\
2 & 95.0 & 1.14 & & 5.0 & 0.06 \\
3 & 92.5 & 1.11 & & 7.5 & 0.09 \\
4 & 90.0 & 1.08 & & 10.0 & 0.12 \\
\hline
\end{tabular}


Table 4. Results of the ignitability fire test by a small-time attack flame of composite

\begin{tabular}{|c|c|c|c|c|c|}
\hline \multirow{2}{*}{ Composite with straw fibers } & \multirow{2}{*}{ Unit } & \multicolumn{4}{|c|}{ The measurement results of the test specimen No. } \\
\hline & & S1 & $\mathrm{S} 2$ & S3 & S4 \\
\hline Percentage & & 2.5 & 5 & 7.5 & 10 \\
\hline Ignitability $\mathrm{Yes} / \mathrm{No}$ & - & No & No & No & No \\
\hline Achieving the flame to the mark $150 \mathrm{~mm} \mathrm{Yes/No}$ & - & No & No & No & No \\
\hline Burning time track $150 \mathrm{~mm}$ & $\mathrm{~s}$ & - & - & - & - \\
\hline \multirow{2}{*}{ Composite with wooden fibers } & \multirow{2}{*}{ Unit } & \multicolumn{4}{|c|}{ The measurement results of the test specimen No. } \\
\hline & & W1 & W2 & W3 & W4 \\
\hline Percentage & & 2.5 & 5 & 7.5 & 10 \\
\hline Ignitability Yes/No & - & No & No & No & No \\
\hline Achieving the flame to the mark $150 \mathrm{~mm} \mathrm{Yes/No}$ & - & No & No & No & No \\
\hline Burning time track $150 \mathrm{~mm}$ & $\mathrm{~s}$ & - & - & - & - \\
\hline
\end{tabular}

tent. The fiber content was $2.5 \%, 5 \%, 7.5 \%$ and $10 \%$ of the total weight of the test specimen. The weight ratios of the individual components are shown in Table 3. The preparation of the test samples was started by weighing the single components. Subsequently, the plaster and fibers were mixed in the vessel. Water was then added to the mixture. The direction was mixed by hand or electric stirrer. Once the optimum consistency has been achieved, the mixture was manually placed into the mold. When filling the mold, the mixture was compacted and pierced to avoid airborne pores. After filling the test form, the mixture was allowed to become quenched. The freezing time for all samples was approximately 15 minutes. After the test sample was tainted, the mold was removed. The same procedure was repeated for all the samples tested. Samples were allowed to cure at $21^{\circ} \mathrm{C}$ and relative humidity of $50 \pm$ $5 \%$. Thereafter, the test specimens were placed in the furnace. The furnace was dried at $40{ }^{\circ} \mathrm{C}$ to remove excess water. The oven drying time was three days. After drying, the samples were left in a laboratory at $21{ }^{\circ} \mathrm{C}$ and relative humidity of $50 \pm 5 \%$ for four days [5]. The dimensions of the test samples conformed to the re-

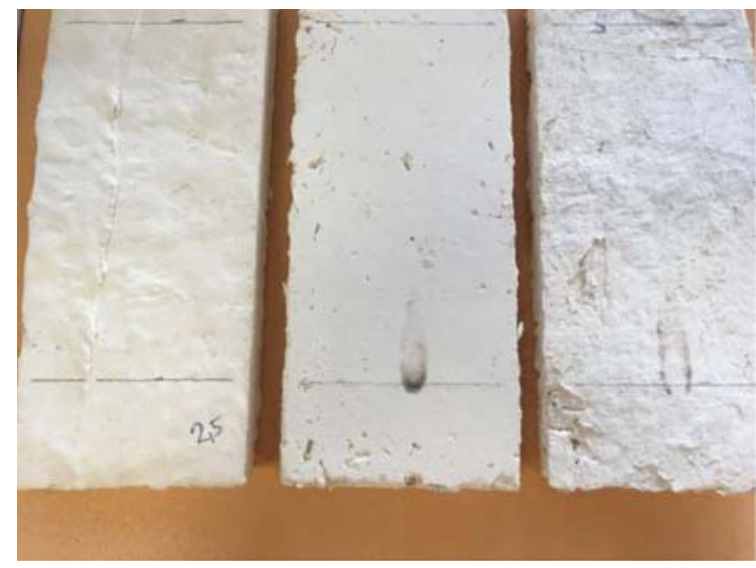

Fig. 4. Test specimens with crushed straw after fire test quirements of the standard. The overall dimensions of test specimens were $230 \mathrm{~mm} \times 90 \mathrm{~mm} \times 15 \mathrm{~mm}$. For samples preparing the building plaster (bonding material), which is a powdered mixture of hemihydrate of calcium sulphate $\left(\mathrm{CaSO}_{4} \cdot 0.5 \mathrm{H}_{2} \mathrm{O}\right)$ with strength G2 (2 MPa) was used. The stalks of straw (filler) were previously crushed with average length of straw stalks within the range of 5 to $10 \mathrm{~mm}$. Diameter of straw fibres is about $0.5 \mathrm{~mm}$ to $1 \mathrm{~mm}$. Length of wooden fibres is maximally $4 \mathrm{~mm}$ and diameter of fibres is about $25 \mu \mathrm{m}$. In a fire laboratory, the test specimens were clamped into a test furnace. Flame calibration was performed with a special dipstick. After calibration of the flame, a fire test was performed on all test specimens. The burner was moved to the position where the flame touched the test specimen surface. Allowing the flame to run for 30 seconds on the surface of the test specimen. no specimen during the test has ignited the surface. For all test specimens, therefore, the requirements were met of the ignitability fire test by a small-time attack flame. Results of ignitability fire test of tested samples are listed in Table 4. Testing specimens after fire test are shown in Figs 4 and 5.

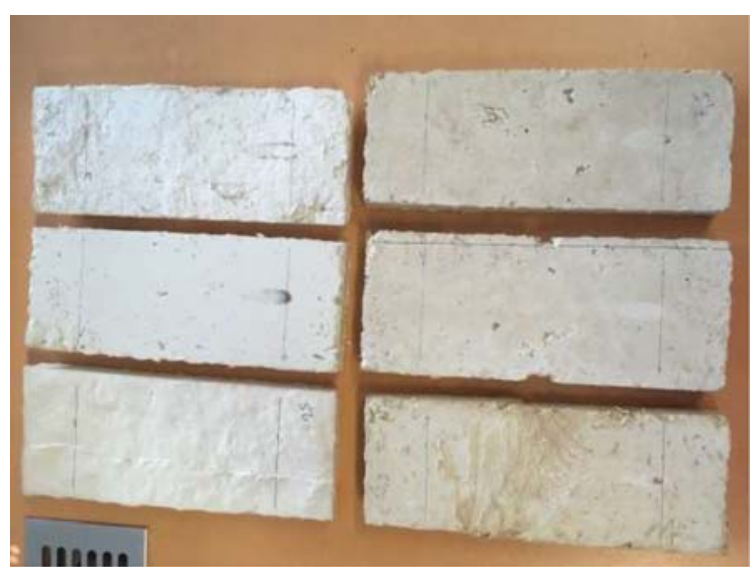

Fig. 5. Test specimens with wooden fibres after fire test 


\section{Conclusion}

The ignitability fire test by a small-time attack flame is part of a comprehensive research of the characteristics of gypsum composites with natural fibres. Fire tests build on the tests of mechanical physical properties. As expected, the gypsum composite has met all fire test requirements. The composite with straw and wood fibers can be classified as better than class $E$ according to their reaction to fire. As part of the further research on gypsum composite, more detailed fire tests will be carried out, which will be able to accurately verify the fire characteristics of the developed composite. On the basis of comparison with similar materials, it can be assumed that the developed composite will be classified into class $A 2$ according to their reaction to fire.

\section{Acknowledgements}

The work was supported by the Student Grant Competition VSB-TUO. Project registration number is SGS SP2018/124.

\section{References}

[1] Hrubá B., Teslík J., Labudek J. (2015), Fire resistance of construction system based on natural materials segments. Nano, bio and green - technologies for a sustainable future. Vol. ii (sgem 2015). Book Series: International Multidisciplinary Scientific GeoConference-SGEM. pp. 141-146.

[2] ČSN EN 13501-1 (2010), Fire classification of construction products and building elements - Part 1: Classification using test data from reaction to fire tests. Praha: Úřad pro technickou normalizaci, metrologii a státní zkušebnictví, $48 \mathrm{~s}$.

[3] Teslík J., Vodičková M., Kutilová K. (2015), The Assessment of Reaction to Fire of Crushed Straw. In: enviBUILD 2015, International Conference Buildings and Environment 2015. 15-16 October 2015, University Library, Ventúrska 11, Bratislava, Slovakia. Bratislava: Slovenská Technická Univerzita, pp. 50-58.

[4] ČSN EN 15101-1, Thermal insulation products for buildings - In-situ formed loose fill cellulose (LFCI) products - Part 1: Specification for the products before installation.

[5] ČSN EN 13279-2, Gypsum binders and gypsum plasters for interior plasters - Part 2: Test methods. 